\title{
EVALUATION OF PARAOXONASE, ARYLESTERASE, AND HOMOCYSTEINE THIOLACTONASE ACTIVITIES IN PATIENTS WITH DIABETES AND INCIPIENT DIABETES NEPHROPATHY
}

\section{PROCENA AKTIVNOSTI PARAOKSONAZE, ARILESTERAZE I HOMOCISTEIN TIOLAKTONAZE KOD BOLESNIKA SA DIJABETESOM I POČETNOM DIJABETIČNOM NEFROPATIJOM}

\author{
Durmuş Ayan ${ }^{1}$, Mehmet Şeneş², Ayşe Banu Çaycı' ${ }^{1}$ Sibel Söylemez¹, Nezaket Eren³, \\ Yüksel Altuntaş ${ }^{4}$, Feyza Yener Öztürk ${ }^{4}$ \\ ${ }^{1}$ Gazi University Faculty of Medicine, Medical Biochemistry, Turkey \\ ${ }^{2}$ Health Sciences University Ankara Education and Research Hospital, Medical Biochemistry, Turkey \\ ${ }^{3}$ Yeni Yüzyıl University Faculty of Medicine, Medical Biochemistry, Turkey \\ ${ }^{4}$ Health Sciences University Sisli Hamidiye Etfal Education and Research Hospital, Endocrinology, Turkey
}

\section{Summary}

Background: The aim of this study is to examine the relationship among the changes in activities of paraoxonase (PON), arylesterase (ARE) and homocysteine thiolactonase (HTLase) enzyme having antioxidant properties and the development of diabetic nephropathy (DN), one of the most common complications of diabetes.

Methods: Normoalbuminuric type-2 diabetic patients (Group II, $\mathrm{n}=100$ ), microalbuminuric type 2 diabetic patients (Group III, $\mathrm{n}=100$ ) and the control group (Group $\mathrm{l}, \mathrm{n}=100$ ) were included in the study. The age and gender of the patient groups matched with the age and gender of the control group. HTLase, PON and ARE enzyme activities were measured by the spectrophotometric method using a $\gamma$-thiobutyrinolactone, paraoxon, and phenylacetate substrates respectively. In this study, an autoanalyzer application was developed in order to measure HTLase enzyme activity for the first time.

Results: Serum HTLase, ARE and PON activities of Group III and Group II were significantly low compared to HTLase, ARE and PON results of Group I $(p<0.05)$.

Conclusions: Based on our results, PON, ARE and HTLase enzyme activities were found to be decreased due to the increase in the degree of DN.

Keywords: paraoxonase, arylesterase, homocysteine thiolactonase

\begin{abstract}
Kratak sadržaj
Uvod: Cilj ovog istraživanja je da se ispita odnos između promena u aktivnostima paraoksonaze ( $P O N)$, arilesteraze (ARE) i homocistein tiolaktonaze (HTLase) sa antioksidativnim svojstvima i razvojem dijabetičke nefropatije (DN), jednog od najčešćih komplikacija dijabetesa.

Metode: U studiju su uključeni bolesnici sa dijabetesom tipa 2 u stanju normoalbuminurije (grupa II, $n=100$ ), pacijenti sa dijabetesom tipa 2, mikroalbuminurnog tipa (III grupa, $n=100$ ) i kontrolna grupa (grupa I, $n=100$ ). Pol pacijenata i njihova starosna dob su se podudarali sa starošću i polom kontrolne grupe. Aktivnost enzima HTLase, PON i ARE je merena spektrofotometrijskom metodom uz korišćenje supstrata $\gamma$-tiobutirinolaktona, paraoksona i fenilacetata. Ovim istraživanjem je razvijena primena autoanalizatora kako bi se prvi put merila aktivnost enzima HTLase.

Rezultati: Aktivnosti serumske HTLaze, ARE i PON kod grupe III i grupe II bile su značajno niske u poređenju sa rezultatima HTLaze, ARE i PON kod grupe I ( $p<0,05)$.

Zaključak: $\mathrm{Na}$ osnovu naših rezultata utvrđeno je da su aktivnosti enzima PON, ARE i HTLase smanjene zbog povećanja stepena DN.
\end{abstract}

Ključne reči: paraoksonaza, arilesteraza, homocistein tiolaktonaza

List of abbreviations: A/C, Albumin/Creatinine; ALT, Alanine aminotransferase; ARE, Arylesterase; AST, Aspartate aminotransferase; BMI, Basal metabolic index; DN, Diabetic Nephropathy; eGFR, Estimated glomerular filtration rate; FBG, Fasting Blood Glucose; Hcy, Homocysteine; HDL, HighDensity Lipoprotein; HTL, Homocysteine Thiolactone; HTLase, Homocysteine Thiolactonase; IQR, Interquartile range; LDL, Low-Density Lipoprotein; PON, Paraoxonase; OS, Oxidative Stress; STD, Standard deviation; T2DM, Type 2 Diabetes Mellitus; TNB, 5-thio-2-nitrobenzoic acid
Durmuş Ayan, Ph.D.

Amasia Central Public Health Laboratory Turkey 


\section{Introduction}

Diabetic nephropathy (DN) is one of the common complications of diabetes and is the main cause of mortality and morbidity in diabetic patients, leading to end-stage renal failure (1). Various types of renal cells are damaged, and DN develops with oxidative stress (OS) caused by increasing free radicals in the presence of ongoing hyperglycemia $(2,3)$. OS plays a key role in atherosclerosis, which is closely related to bioactive lipid species and the inflammatory response (4-6).

Human serum paraoxonase $(P O N-1)$ is an enzyme found in high-density lipoprotein (HDL) and has a strong antioxidant property. It protects both HDL and low-density lipoprotein (LDL) against OS. Studies have shown that PON-1 changes with OS have a role in the development of atherosclerosis (7). $\mathrm{PON}-1$ is also a multifunctional antioxidant enzyme since it has paraoxonase (PON), arylesterase (ARE) and homocysteine thiolactonase (HTLase) activity (7, 8). PON-1 enzyme detoxifies homocysteine thiolactone (HTL) as well as degrading oxidized LDL molecules (9). HTL has been identified by Jakubowski et al. (11) as a metabolite being more active than homocysteine (Hcy), which mediates the toxic and damaging effects of Hcy (10-13). HTLase being a component of HDL hydrolyzes HTL to Hcy. Endothelial damage especially caused by homocysteinylation of LDL will be prevented by performing HTL detoxification. HTLase is a product of the polymorphic PON-1 gene. High HTLase activity has been reported to provide better protection against protein homocysteinylation compared to low HTLase activity (7). Recent studies have demonstrated that PON-1 and ARE are enzymes in the esterase group that are encoded by the same gene and whose active centres are similar $(14,15)$. Although PON-1 is known to present polymorphic changes, ARE enzyme does not show any genetic polymorphism (16). The PON-1 enzyme has an antioxidant function due to its protective properties targeting LDL against oxidation as well. It is also able to neutralize other radicals, including hydrogen peroxide (17). On the other hand, ARE is considered to be the indicator of the original protein that is not affected by changes in PON-1 (18).

In this study, the aim is to examine the relationship between the changes in PON, HTLase and ARE enzyme activities and the development of $D N$, one of the most common complications of diabetes.

\section{Materials and Methods}

\section{Subjects}

A total of 300 patients including 100 normoalbuminuric type 2 Diabetes Mellitus (T2DM) (Group II), 100 microalbuminuric T2DM patients (Group III), and 100 healthy control subjects (Group I) with nor- moalbuminuria were included in the study. Patient groups were age and gender-matched with the age and gender of the control group. Spot urine albu$\mathrm{min} /$ creatinine $(\mathrm{A} / \mathrm{C})$ ratios of patient groups within the last 6 months were considered when DN status was identified. Patients who had an $\mathrm{A} / \mathrm{C}$ ratio of $<30$ $\mathrm{mg} / \mathrm{g}$ for 3 times within the last 6 months were classified as normoalbuminuric, and those who had an $\mathrm{A} / \mathrm{C}$ ratio of $30-299 \mathrm{mg} /$ day for 3 times within the last 6 months were classified as microalbuminuric. Latest $A / C$ values of patients were included in the study.

Among patients with T2DM, patients with cardiovascular diseases, chronic infections, liver pathology, hypertension, any renal pathology other than DN, smokers, alcohol users, those receiving antihyperlipidemic drugs and antioxidant supplements, and those with a Body Mass Index (BMI) >30 were excluded from the study. For the control group, participants were selected from healthy volunteers with no previous diabetes history. In addition, participants taking B12, B6 and folic acid supplementation in the last two months were excluded from the control group and the patient groups. We had a survey including questions on demographics, diet, and other lifestyle factors. Within the scope of the survey, we included patients with a similar diet and lifestyle. A signed informed consent form was obtained from all patients and the control group in terms of their participation in the study. Ethics committee approval was obtained from the Health Sciences University i li Hamidiye Etfal Training, and Research Hospital Ethics Committee dated 23/12/2014 and numbered 815. The study was conducted in accordance with the principles of the Helsinki declaration.

\section{Blood and Urine Sampling}

Blood samples were collected in Vacutainer SST tubes (Becton Dickinson) with gel separator and EDTA tubes (only for Hcy and $\mathrm{HbA} 1 \mathrm{c}$ analysis) (Becton Dickinson), following a 10 to 12-hour fasting in the patient and control group. Blood samples (SST tubes) which were taken from patient and control groups were centrifuged at $4000 \mathrm{rpm}$ for 10 minutes and $2500 \mathrm{rpm}$ for 10 minutes EDTA containing tubes. Triglyceride, Total Cholesterol, HDL, LDL, Glucose, aspartate aminotransferase (AST), alanine aminotransferase (ALT), B12, Folate, Creatinine, Hcy, and $\mathrm{HbA} 1 \mathrm{c}$ were analyzed on the same day and stored at $-80{ }^{\circ} \mathrm{C}$ for studying PON, ARE and HTLase enzymes.

\section{Routine Laboratory Analyses}

Preprandial blood glucose (FBG), triglyceride, cholesterol, HDL, creatinine, Hcy, AST, ALT, urine albumin, and urine creatinine levels were measured 
spectrophotometrically using a Cobas c501 autoanalyzer (Roche Diagnostic, USA) and vitamin B12, folic acid levels were measured by electrochemiluminescence method using a Cobas e601 immunoassay device (Roche Diagnostic, USA). LDL levels were calculated using the Friedewald formula. HbA1c was measured by HPLC (high-pressure liquid chromatography) method on the Tosoh G8 Analyzer (Tosoh Bioscience, South San Francisco, CA). Estimated glomerular filtration rate (eGFR) was calculated using the Schwartz formula.

\section{Paraoxonase measurement}

The method developed by Eckerson et al. (1983) was used for measuring PON activity (19). The method is based on the conversion of paraoxonase (diethyl p-nitrophenyl phosphate) (Sigma Aldrich, St. Louis, Missouri, ABD) to diethyl phosphate and p-nitrophenol by $\mathrm{PON}$ found in human serum. The increase in absorbance of the resulting $p$ nitrophenol is measured spectrophotometrically at a wavelength of $412 \mathrm{~nm}$. The method was applied to a Beckman Coulter AU-680 analyzer (Mishima Beckman Coulter Co. Ltd. U.S.A.). The wavelength where p-nitrophenol shows maximum absorbance is 412 $\mathrm{nm}$. Therefore, the absorbance measurements on the spectrophotometer were made at a wavelength of $412 \mathrm{~nm}$. The molar absorbance coefficient of p-nitrophenol was calculated as $\varepsilon_{412}=18000 \mathrm{M}^{-1} \mathrm{~cm}^{-1}$. 1 unit of PON activity creates $1 \mu \mathrm{mol}$ of p-nitrophenol per minute. Paraoxonase activity was calculated as $\mathrm{U} / \mathrm{L}$. The molar absorbance coefficient calculated by the absorbance at $412 \mathrm{~nm}$ in the spectrophotometer was used in the PON calculation measured in the autoanalyzer. For PON, the value of LOQ (Limit of quantification) was found to be $6.55 \mathrm{U} / \mathrm{L}$ and the value of LOD (Limit of detection) was found to be 6.5 $\mathrm{U} / \mathrm{L}$. The values of linearity were $6.5-300 \mathrm{U} / \mathrm{L}$.

\section{Homocysteine thiolactonase measurement}

The method involves the hydrolysis of the thiolactone ring of $\gamma$-thiobutyrinolactone (Sigma Aldrich, St. Louis, Missouri, ABD) added as substrate by the HTLase enzyme present in the serum, the released free thiol groups to form 5-thio-2-nitrobenzoic acid (TNB) with Ellman's reactive 5,5', dithiobis (2-nitrobenzoic acid), and measuring enzyme activity based on this product. The wavelength at which TNB shows maximum absorbance is $450 \mathrm{~nm}$. Thus, the absorbance measurements were made on a spectrophotometer at a wavelength of $480 \mathrm{~nm}$. The molar absorbance coefficient of TNB was calculated as $480=10695 \mathrm{M}^{-1} \mathrm{~cm}^{-1} .1$ unit of thiolactonase activity forms $1 \mu \mathrm{mol}$ of TNB per minute. The molar absorbance coefficient calculated by the absorbance values measured at $480 \mathrm{~nm}$ was used in the HTLase calculation measured by an auto analyzer. The modified version of the method described by Billecke was used (20). This method was applied to a Beckman Coulter AU-680 biochemical autoanalyzer (Mishima Beckman Coulter Co. Ltd. U.S.A.) for the first time in our study. For HTLase, the values of LOQ, LOD, and linearity range were found to be $9.75 \mathrm{U} / \mathrm{L}, 3.85 \mathrm{U} / \mathrm{L}$ and 3.85-757 $\mathrm{U} / \mathrm{L}$ respectively.

\section{Arylesterase measurement}

ARE activity was determined spectrophotometrically by measuring the absorbance increase at 270 $\mathrm{nm}$. It was caused by the coloured compound produced by phenol resulting from the enzymatic hydrolysis of phenylacetate (Sigma Aldrich, St. Louis, Missouri, ABD) used as a substrate. Activity measurement was performed based on the method developed by Eckerson et al. (19) and the absorbance change after 20 seconds lag time was monitored up to the 1st minute, and the difference was recorded as the absorbance value. The molar absorbance coefficient of phenol at $270 \mathrm{~nm}$, accepted as $\mathrm{kU} / \mathrm{L}$ was taken as $270=1310 \mathrm{M}^{-1} \mathrm{~cm}^{-1}$. ARE enzyme activity was measured using a Shimadzu UV-spectrophotometer UV1700 (Shimadzu Corporation, Japan). The values of $L O Q, L O D$, and linearity range for ARE were found as $3.3 \mathrm{U} / \mathrm{L} 2.5 \mathrm{U} / \mathrm{L}$ and 2.5-91 U/L respectively.

\section{Statistical Analysis of Data}

SPSS 15.0 software for Windows was used for statistical analysis. Descriptive statistics were provided as numbers and percentages for categorical variables; and mean, IQR (interquartile range), standard deviation, median for numerical variables. Normal distribution was determined by examining Skewness and Kurtosis values, Kolmogorov-Smirnov tests, ShapiroWilk tests and examining the distribution of histograms. One Way ANOVA and Tukey host test were used for multiple group comparisons ( 3 groups) fitting normal distribution. Kruskal-Wallis and Dunn's pairwise tests were used for multiple group comparisons ( 3 groups) in terms of non-fitting normal distribution. Proportions of categorical variables between groups were tested by chi-square analysis. A statistical significance level of alpha was accepted as $p<0.05$. In correlation analyses, Pearson Correlation Analysis was performed when the parametric test condition was met for numerical variables, and Spearman Correlation Analysis was used when the parametric test condition was not met. In addition, multivariate logistics regression and ordinal regression analyses were used in order to reveal the relationship between dependent and independent variables.

\section{Results}

Baseline values of clinical characteristics of Group II ( $n=100,50$ males, 50 females), Group III ( $n=100,50$ males, 50 females), and Group I 
Table I Correlations between the HTLase activity (IU/L) and the other parameters.

\begin{tabular}{|l|c|c|c|c|}
\hline \multirow{2}{*}{} & \multicolumn{2}{|c|}{ Group II $(\mathrm{n}=100)$} & \multicolumn{2}{c|}{ Group III $(\mathrm{n}=100)$} \\
\cline { 2 - 5 } & $\mathrm{r}$ & $\mathrm{p}$ & $\mathrm{r}$ & $\mathrm{p}$ \\
\hline PON (IU/L) & 0.501 & $0.01^{* *}$ & 0.671 & $0.01^{* *}$ \\
\hline ARE $(\mathrm{IU} / \mathrm{L})$ & 0.582 & $0.01^{* *}$ & 0.422 & $0.01^{* *}$ \\
\hline $\mathrm{Hcy}(\mathrm{mmol} / \mathrm{L})$ & -0.039 & 0.797 & -0.127 & 0.378 \\
\hline $\mathrm{A} / \mathrm{C}(\mu \mathrm{g} / \mathrm{mg})$ & 0.772 & $0.025^{*}$ & 0.863 & $0.01 * *$ \\
\hline
\end{tabular}

( $n=100,50$ males, 50 females) were shown in Table l. Age and gender of the patient groups were matched with each other and with the control group. No statistically significant difference was found between serum LDL $(p=0.459)$, cholesterol $(p=0.591)$, $\operatorname{AST}(p=0.392), \operatorname{ALT}(p=0.382), B 12(p=0.612)$, folate $(p=0.058)$, plasma Hcy results $(p=0.710)$ and eGFR values $(p=0.745)$ when the patient groups were compared with the control group. Serum HDL levels of Group II and Group III were significantly low compared to the levels of the control group

Table II Median, interquartile range and standard deviation values for all groups.

\begin{tabular}{|c|c|c|c|c|}
\hline Tests & $\begin{array}{c}\text { Group I } \\
(n=100) \text { control }\end{array}$ & $\begin{array}{c}\text { Group II } \\
(\mathrm{n}=100) \\
\text { T2DM normoalbumin }\end{array}$ & $\begin{array}{c}\text { Group III } \\
(n=100) \\
\text { T2DM microalbumin }\end{array}$ & $\mathrm{p}$ values \\
\hline & $\begin{array}{c}\text { mean } \pm \text { std deviation/ } \\
\text { median-IQR }\end{array}$ & $\begin{array}{c}\text { mean } \pm \text { std } \\
\text { deviation/median-IQR }\end{array}$ & $\begin{array}{c}\text { mean } \pm \text { std } \\
\text { deviation/median-IQR }\end{array}$ & \\
\hline Age (year) & $54.5(44-60)$ & $54.5(44-60)$ & $54.5(44-60)$ & - \\
\hline Gender & 50 males, 50 females & 50 males, 50 females & 50 males, 50 females & \\
\hline $\mathrm{BMI} \mathrm{kg} / \mathrm{m}^{2}$ & $24.74 \pm 3.45$ & $25.91 \pm 2.48$ & $26.05 \pm 29.72$ & 0.523 \\
\hline Diabetes duration (year) & non-diabetic group & $6(5-9)$ & $6(5-8)$ & - \\
\hline eGFR mL/min/1,73 $\mathrm{m}^{2}$ & $95.6 \pm 10.4$ & $90.8 \pm 8.4$ & $91.4 \pm 9.3$ & 0.745 \\
\hline FBG (mmol/L) & $4.9(4.6-5.2)$ & $10.7(7.4-14.2)$ & $9.9(7.6-12.9)$ & $0.001 * *$ \\
\hline Creatinine $(\mu \mathrm{mol} / \mathrm{L})$ & 77.8 (65.4-88.4) & $68.1(53.0-82.2)$ & 58.3 (48.6-76.9) & $0.016^{*}$ \\
\hline HbA1c (\%) & $5.3(5.1-5.5)$ & $8.4(7.4-10.1)$ & $8.4(7.2-9.6)$ & $0.001 * *$ \\
\hline $\mathrm{HDL}(\mathrm{mmol} / \mathrm{L})$ & $1.4 \pm 0.5$ & $1.2 \pm 0.4$ & $1.1 \pm 0.3$ & $0.009 * *$ \\
\hline LDL (mmol/L) & $2.8(2.2-3.1)$ & $2.9(2.4-3.4)$ & $2.7(2.1-3.3)$ & 0.459 \\
\hline Triglyceride (mmol/L) & $1.0(0.8-1.3)$ & $1.5(1.2-2.2)$ & $1.7(1.1-2.7)$ & $0.001 * *$ \\
\hline Cholesterol (mmol/L) & $4.7(3.1-4.1)$ & $5.0(4.2-5.5)$ & $4.8(4.0-5.5)$ & 0.591 \\
\hline AST (IU/L) & $19(16-24)$ & $18(15-23)$ & $19.5(14-23)$ & 0.392 \\
\hline ALT (IU/L) & $19(15-30)$ & $22(17-28)$ & $21(14-31)$ & 0.382 \\
\hline B12 (pmol/L) & 278.6 (225.4-319.1) & $254.5(194.0-318.6)$ & $237.2(187.5-318.2)$ & 0.612 \\
\hline Folate (nmol/L) & $23.1(20.2-27.6)$ & $25.8(20.6-31.0)$ & $24.2(18.3-28.1)$ & 0.058 \\
\hline Urine albumin (mg/L) & $8.4(5.7-14.4)$ & $13.4(8.8-19.6)$ & 94.9 (46.6-163.5) & $0.001 * *$ \\
\hline Urine Creatinine $(\mathrm{mg} / \mathrm{dL})$ & 169.6 (91.9-230.9) & 136.2 (86.8-156.6) & 107.5 (62.8-170.5) & 0.105 \\
\hline $\mathrm{A} / \mathrm{C}$ ratio $(\mathrm{mg} / \mathrm{g})$ & $4.8(3.5-8.4)$ & $10.4(7.3-21.3)$ & 95.9 (53.8-128.7) & $0.001 * *$ \\
\hline HTLase (IU/L) & $635.5 \pm 124.4$ & $615 \pm 132.9$ & $596.8 \pm 150.6$ & $0.023^{*}$ \\
\hline PON-1 (IU/L) & 97.5 (39.5-133.5) & $96.0(36.1-133.3)$ & 34.5 (24.8-112.0) & $0.025^{\star}$ \\
\hline ARE (kU/L) & $57.1(50.1-65.6)$ & $53.1(39.1-61.7)$ & $44.9(36.1-58.6)$ & $0.006 * *$ \\
\hline Hcy $(\mu \mathrm{mol} / \mathrm{L})$ & $9.6(7.8-13.6)$ & 9.87 (8.54-13.16) & 9.98 (8.53-13.55) & 0.710 \\
\hline
\end{tabular}

* $\mathrm{p}<0.05, * * \mathrm{p}<0.01$

Abbreviations: FBG, Fasting Blood Glucose; HDL, High-Density Lipoprotein; LDL, Low-Density Lipoprotein; AST, Aspartate Aminotransferase; ALT, Alanine Aminotransferase; A/C, Albumin/Creatinine; HTLase, Homocysteine Thiolactonase; PON-1, Paraoxonase-1; ARE, Arylesterase; Hcy, Homocysteine; std, standard deviation; IQR, interquartile range. 
( $p=0.009$ ). HTLase results of Group II and Group III were significantly low compared to HTLase results of Group I $(p=0.023)$. Serum PON levels of Group II and Group III were significantly low compared to the control group $(p=0.025)$. Serum ARE levels of Group II, and Group III were significantly low compared to the control group $(p=0.009)$. The correlation results of the groups were presented in Table $I$.

\section{Discussion}

In this study, changes in the activities of PON, ARE and HTLase enzymes showing PON-1 enzyme activity were examined with respect to nephropathy, one of the most common complications due to T2DM. We have also examined whether these enzyme activities are suitable markers for the early diagnosis of DN. Research only analyzed enzyme activity in patients with incipient diabetic nephropathy comparing to patients with or without diabetes and without microalbuminuria. In our study, a spectrophotometric measurement method for HTLase enzyme activity was developed for a biochemical autoanalyzer (Beckman Coulter AU-680) for the first time.

Our initial findings of decreasing PON, ARE and HTLase enzyme activities in DN support the hypothesis that advanced glycation of structural proteins and OS one of the main mechanisms in the development of diabetic complications (21). We studied normoalbuminuric patients with T2DM (Group II, $n=100$ ) and microalbuminuric patients with T2DM (Group III, $n=100$ ). The control group (Group I, $n=100$ ) consisted of healthy volunteers. The OS caused by diabetes affects PON, ARE and HTLase enzyme activities, which have antioxidant capacity. As the level of OS increases, enzyme activity decreases $(7,22)$. In the study, we determined that PON, HTLase and ARE enzyme activities in Group III were lower than PON, HTLase and ARE enzyme activities in Group II. When enzyme activities were compared with the control group consisting of healthy volunteers, it was concluded that the serum enzyme activity results of the patient groups were lower than that of the control group except for the serum HTLase activity of Group II. The elevated serum HTLase activity of Group II compared to Group I can be interpreted as an increase in the expression of the enzyme as an antioxidant defense mechanism.

There are three members of the paraoxonase gene family: PON1, PON2, and PON3. PON1 exhibits paraoxonase, arylesterase and lactonase activity. PON2 and PON3 have lactonase activity but do not exhibit paraoxonase and arylesterase activity (23). Previous studies have reported findings of an association between PON-1 enzyme activities and diabetes. Suvarna et al. examined the change of PON-1 enzyme activity in the diabetic patient group and healthy volunteer group and found that serum
PON-1 enzyme activity was lower in diabetic patients. In addition, the diabetic patient group was divided into two groups as those with diabetic complications and those without diabetic complications, and serum PON-1 activity was found to be lower in patients with complications compared to those without complications (24). In our study, DN grade was determined according to $\mathrm{A} / \mathrm{C}$ ratio, and $\mathrm{PON}-1$ activity was found to be lower in diabetic patients who developed nephropathy. In a study conducted by Gawade et al. (25) serum PON-1 activities were evaluated in diabetic patient groups with and without nephropathy. Serum PON-1 enzyme activity was found to be lower in the diabetic patient group who developed nephropathy, and it has been reported that this may be related to the pathophysiology of DN (25). In another study conducted by Sabah et al. (26) serum PON-1 enzyme activity was found to be low in the diabetic patient group developing microvascular complications. It was concluded that a decreasing change in serum PON-1 enzyme activity was a deterministic risk factor for microvascular complications of diabetes mellitus. It was also suggested that renal vascular damage in diabetic patients could be reduced by preserving serum PON-1 activity by treating patients with antioxidant substances at therapeutic doses (26).

Although PON enzyme is known to demonstrate polymorphic changes, ARE enzyme does not show any genetic polymorphisms. PON enzyme has antioxidant function due to its protective properties against LDL oxidation and its ability to neutralize other radicals, including hydrogen peroxide $(16,18)$. On the other hand, ARE is considered to be the primary protein marker not affected by changes in PON-1 (16) and decreased activity in both enzymes occurs with increased glycation and increased $O S$ in diabetic patients, resulting in loss of function (27). HTL, which is a more active intermediate metabolite than $\mathrm{Hcy}$, causes homocysteinylation of proteins. LDL and HDL are particularly affected by this homocysteinylation. HTLase hydrolyzes HTL and protects LDL and HDL against this situation. HTLase and PON-1 are also referred to as similar enzymes because HTLase exhibits PON-1 activity. In light of this information, metabolic changes that occur in diabetes will lead to loss of activity in HTLase enzyme and will provide the basis for the development of cardiovascular events in diabetic patients (28).

In our study, changes in PON, ARE and HTLase enzyme activities, which exhibit serum PON-1 activity and have similar characteristics, were evaluated in the early phase of DN. ARE and PON were encoded by the same gene and their active centres were found to be similar. However, the major difference between these enzymes was that PON exhibited polymorphic changes whereas ARE did not exhibit genetic polymorphisms (16). When we evaluated serum ARE enzyme activity in our study, the possibility of PON enzyme exhibiting genetic polymorphism was taken 
into consideration. When HTLase activity was evaluated, all three enzyme activities were assessed together. The failure of removing HTL active metabolite of Hcy from the body would support the development process of atherosclerosis, and HTLase enzyme had antioxidant capacity. According to the results of our study, serum PON, ARE and HTLase enzyme activities were found to be significantly lower in patients with DN compared to diabetic patients without nephropathy $(p<0.05)$. Craciun et al. (29) assessed the activity of all enzymes exhibiting PON-1 activity and noted a reduction in the activity of these enzymes in diabetic patients. However, a significant loss of activity was observed in HTLase activity (29). DN may not be detected at first. Albumin excretion in patients' urine may be normoalbuminuric, and microalbuminuria and macroalbuminuria may develop later, leading to an end-stage renal failure. In the study of Tabur et al. (30) where PON and ARE enzyme activities of diabetic patients grouped as normoalbuminuria and microalbuminuria according to the degree of microalbuminuria were examined in conjunction with the OS caused by diabetes, it was concluded that the activities of these enzymes were lower in the microalbuminuria group. Bayrak et al. (31) conducted a study on patient groups with impaired FBG and impaired glucose tolerance and investigated changes in HTLase activity compared to healthy volunteers. In conclusion, HTLase activity was found to be significantly low in all three groups compared to the control group, and it was reported that the reduction in HTLase activity in the prediabetic phase was associated with cardiovascular risk (31). Kosaka et al. (32) evaluated HTLase activity in patients with T2DM and argued that increased carotid intima-media thickness in patients with T2DM was inversely correlated with HTLase activity, and a reduction in serum HTLase activity could provide data about the status of atherosclerosis in patients with T2DM (32).

Koubaa et al. (33) examined plasma total Hcy levels, HTLase activity, lipid panel (LDL, HDL, TG, Total Cholesterol), lipoprotein (ApoA1 and ApoB) and oxidized LDL levels of diabetic patient group and nondiabetic healthy volunteers. It was found that HTLase activity was statistically significantly low in the patient group compared to the control group, and Hcy and oxidized LDL levels were significantly elevated in the

\section{References}

1. Osonoi T, Gouda M, Kubo M, Arakawa K, Hashimoto T, Abe M. Effect of Canagliflozin on Urinary Albumin Excretion in Japanese Patients with Type 2 Diabetes Mellitus and Microalbuminuria: A Pilot Study. Diabetes Technology \& Therapeutics 2018.

2. Kumar Pasupulati A, Chitra PS, Reddy GB. Advanced glycation end products mediated cellular and molecular events in the pathology of diabetic nephropathy. Biomolecular Concepts 2016;7(5-6): 293-309. patient group. It was reported that the increase in Hcy levels in diabetic patients was due to a decrease in HTLase activity and elevated Hcy levels in diabetic patients would impair lipid metabolism in particular by contributing to the formation of oxidized LDL and therefore accompany atherosclerosis-related complications (33). In our study, no statistical significance was found between plasma Hcy levels in both group II and group III ( $p>0.05)$. Furthermore, when the correlation results of both groups were examined, no correlation was observed between Group II plasma Hcy values and HTLase ( $r$ : $-0.039, p=0.797)$ and between Group III plasma Hcy values and HTLase ( $r$ : $-0.127, p=0.378$ ) in our study.

\section{Conclusions}

Uncontrolled diabetes is a very dangerous situation due to increased glycation in the body. We believe that the regulation of oxidant-antioxidant impairment due to excessive glycation can prevent diabetic complications once diabetic control is established and especially slowed down the atherosclerotic process. Based on our results, PON, ARE and HTLase enzyme activities were found to be decreased in patients with incipient diabetic nephropathy.

\section{Limitations}

Although the study has been carefully prepared, I am still aware of its limitations and shortcomings. Firstly, the number of participants can be increased, and gender differences can be examined, resulting in a wide range of data for Turkish society for males and females. Secondly, when we assessed homocysteine levels in our study, we could not evaluate the active metabolite, homocysteine thiolactone. Homocysteine thiolactone levels should be assessed in these patient groups and data could be obtained about the role of homocysteine thiolactone in the development of DN.

\section{Conflict of interest statement}

The authors stated that they have no conflicts of interest regarding the publication of this article.

3. Elmarakby AA, Sullivan JC. Relationship between Oxidative Stress and Inflammatory Cytokines in Diabetic Nephropathy. Cardiovascular Therapeutics 2012; 30(1): 49-59.

4. Kattoor AJ, Pothineni NVK, Palagiri D, Mehta JL. Oxidative Stress in Atherosclerosis. Current Atherosclerosis Reports 2017;1 9(11): 42.

5. Puhalo Sladoje D, Kisić B, Mirić D. The monitoring of protein markers of inflammation and serum lipid concen- 
tration in obese subjects with metabolic syndrome. J Med Biochem 2017; 36: 366-74.

6. Yang X, Li Y, Li Y, Ren X, Zhang X, Hu D, et al. Oxidative Stress-Mediated Atherosclerosis: Mechanisms and Therapies. Frontiers in Physiology 2017; 8: 600.

7. Shunmoogam N, Naidoo P, Chilton R. Paraoxonase (PON)-1: a brief overview on genetics, structure, polymorphisms and clinical relevance. Vascular Health and Risk Management 2018; 14: 137-43.

8. Perla-Kajan J, Jakubowski H. Paraoxonase 1 protects against protein $\mathrm{N}$-homocysteinylation in humans. FASEB journal: official publication of the Federation of American Societies for Experimental Biology 2010; 24(3): 931-6.

9. Benedetti S, Catalani S, Peda F, Luchetti F, Citarella R, Battistelli S. Impact of the 24-h ultramarathon race on homocysteine, oxidized low-density lipoprotein, and paraoxonase 1 levels in professional runners. PloS one 2018; 13(2): e0192392.

10. Lippi G, Cadamuro J. Novel Opportunities for Improving the Quality of Preanalytical Phase. A Glimpse to the Future? J Med Biochem 2017; 36: 293-300.

11. Jakubowski H, Ambrosius WT, Pratt JH. Genetic determinants of homocysteine thiolactonase activity in humans: implications for atherosclerosis. FEBS letters 2001; 491(1-2): 35-9.

12. Lacinski M, Skorupski W, Cieslinski A, Sokolowska J, Trzeciak WH, Jakubowski H. Determinants of homocysteine-thiolactonase activity of the paraoxonase-1 (PON1) protein in humans. Cellular and Molecular Biology (Noisy-le-Grand, France) 2004; 50(8): 885-93.

13. Yilmaz N. Relationship between paraoxonase and homocysteine: crossroads of oxidative diseases. Archives of Medical Science: AMS 2012; 8(1): 138-53.

14. Zargari M, Sharafeddin F, Mahrooz A, Alizadeh A, Masoumi P. The common variant Q192R at the paraoxonase 1 (PON1) gene and its activity are responsible for a portion of the altered antioxidant status in type 2 diabetes. Experimental Biology and Medicine (Maywood, NJ) 2016; 241(14): 1489-96.

15. Varga E, Seres I, Harangi M, Kárpáti I, Koncsos $P$, Sztanek F, et al. Low High-Density Lipoprotein Cholesterol Is Not Responsible for Decreased Paraoxonase Activity in Chronic Renal Failure. Kidney and Blood Pressure Research 2012; 35(4): 265-72.

16. Gürsu MF, Özdin M. Sigara içenlerde serum paraoksonaz (PON-1) aktiviteleri ile malondialdehit düzeylerinin ara tırılması. Fırat Tıp Dergisi 2002; 7(2): 732-7.

17. Cervellati C, Trentini A, Romani A, Bellini T, Bosi C, Ortolani $B$, et al. Serum paraoxonase and arylesterase activities of paraoxonase-1 (PON-1), mild cognitive impairment, and 2-year conversion to dementia: A pilot study. Journal of Neurochemistry 2015; 135(2): 395-401.

18. Türkoğlu S, Bulmuş FG, Parmaksiz A, Özkan Y, Gürsu F. Metabolik sendromlu hastalarda paraoksonaz 1 ve arilesteraz aktivite düzeyleri. Fırat Tıp Dergisi 2008; 13(2): 110-5.

19. Eckerson HW, Wyte CM, La Du BN. The human serum paraoxonase/arylesterase polymorphism. American Journal of Human Genetics 1983; 35(6): 1126-38.
20. Billecke S, Draganov D, Counsell R, Stetson P, Watson C, Hsu $C$, et al. Human serum paraoxonase (PON1) isozymes $\mathrm{Q}$ and $\mathrm{R}$ hydrolyze lactones and cyclic carbonate esters. Drug metabolism and disposition: the biological fate of chemicals 2000; 28(11): 1335-42.

21. Ünüvar S, Tanrıverdi Z, Aslanhan H. Potential prognostic role of immune system activation marker neopterin in patients with type 2 diabetes. J Med Biochem 2018, 37; 465-9.

22. Adhe-Rojekar A, Mogarekar MR, Rojekar MV. Paraoxonase activity in metabolic syndrome in children and adolescents. Caspian Journal of Internal Medicine 2018; 9(2): 116-20.

23. Gugliucci A, Kinugasa E, Kotani K, Caccavello R, Kimura S. Serum paraoxonase 1 (PON1) lactonase activity is lower in end-stage renal disease patients than in healthy control subjects and increases after hemodialysis. Clinical Chemistry and Laboratory Medicine 2011; 49(1): 61-7.

24. Suvarna R, Rao SS, Joshi C, Kedage V, Muttigi MS, Shetty JK, et al. Paraoxonase activity in type 2 diabetes mellitus patients with and without complications. Journal of Clinical and Diagnostic Research 2011; 5(1): 63-5.

25. Gawade G, Padwal MK, Melinkeri RR. Oxidative stress and paraoxonase (PON-1) status in diabetic nephropathy. International Journal of Health Sciences and Research 2015; 5(12): 177-84.

26. Sabah AM, Reham S, Eman S. Role of paraoxonase activity and oxidative stress in renal vascular damage in type 2 diabetes mellitus. Clinical Medicine and Diagnostics 2015; 5(2): 26-34.

27. Caner C, Özeç AV, Aydın H, Topalkara A, Arıcı MK, Erdo an $\mathrm{H}$, et al. Comparison of total oxidative stress, total antioxidant capacity, paraoxonase, arylesterase, lipid peroxidase levels in humor aquos and serum at diabetic and nondiabetic patients with cataract. Turkish Journal of Ophthalmology 2012; 42: 47-52.

28. Lakshman MR, Gottipati CS, Narasimhan SJ, Munoz J, Marmillot P, Nylen ES. Inverse correlation of serum paraoxonase and homocysteine thiolactonase activities and antioxidant capacity of high-density lipoprotein with the severity of cardiovascular disease in persons with type 2 diabetes mellitus. Metabolism 2006; 55(9): 1201-6.

29. Craciun EC, Leucuta DC, Rusu RL, David BA, Cret V, Dronca E. Paraoxonase-1 activities in children and adolescents with type 1 diabetes mellitus. Acta Biochimica Polonica 2016; 63(3): 511-5.

30. Tabur S, Korkmaz H, Eren MA, Oguz E, Sabuncu T, Aksoy N. Urotensin-II level and its association with oxidative stress in early diabetic nephropathy. Journal of Diabetes and it's Complications 2015; 29(1): 115-9.

31. Bayrak T, Bayrak A, I ıldak M, Çakır E, Gürlek A, Akbıyık F. Increased Asymmetric Dimethylarginine (ADMA) levels and decreased Homocysteine Thiolactonase/Paraoxonase (HTLase/PONase) activities are related to the risk of cardiovascular disease in prediabetic/diabetic patients. Turkish Journal of Biochemistry 2014; 39(3): 270-6. 
32. Kosaka T, Yamaguchi M, Motomura T, Mizuno K. Investigation of the relationship between atherosclerosis and paraoxonase or homocysteine thiolactonase activity in patients with type 2 diabetes mellitus using a commercially available assay. Clinica Chimica Acta; International Journal of Clinical Chemistry 2005; 359(1-2): 156-62.
33. Koubaa N, Nakbi A, Betbout F, Hamda KB, Smaoui M, Frih $M A$, et al. Interactions between total plasma homocysteine, oxidized LDL levels, thiolactonase activities and dietary habits in Tunisian diabetic patients. Tunisia: Citeseer; 2011.

Received: March 3, 2018

Accepted: January 29, 2019 